\title{
LITHIUM BATTERY HANDLING AS AIR CARGO
}

\section{Wynd Rizaldy', Simon Gultom ${ }^{2}$, Salahuddin Raffi ${ }^{3}$, Agus Setiawan ${ }^{4}$}

\author{
1. STMT Trisakti, 2. STMT Trisakti, 3. STMT Trisakti, 4. STMT Trisakti \\ $\triangle$ Corresponding author: wyndrizaldy@gmail.com
}

\begin{abstract}
The paper objective is to maintain flight safety and zero accident related to handling of Lithium battery during flight. "Flight safety determined by various factors which related to human factors, both prelight and in-flight service"(Kania, 2016). This Paper review and analyze the Lithium Battery handling's section on International Air Transport Association Dangerous Goods Regulation (IATA DGR) latest edition, especially related to United Number and Packing Instruction for four types of Lithium Battery with UN3480-PI965, UN3481-PI966/967, UN3090-PI968, UN3091-PI969/970 about Lithium Battery types, packing, documentation and handling. On the other hand, it is also found that the company has some weaknesses such as lack of transport owned by the vendor, lack of supervised-material system, undetailed-packing process, less communication and coordination between branches and the minimum number of vendors (Azhar \& Rizaldy, 2015) this could be risk in handling of the Lithium Battery. This paper method is descriptive-explorative using a quantitative qualitative data source from International Civil Aviation Organization Technical Instruction (ICAO TI), and IATA DGR, Recommendation from Pilot Association, public policy analysis and Forum Group Discussion (FGD) and Dangerous Goods Panel (DGP) on the workshop related to the Lithium Battery specifically. The results of this paper is encourage party especially between warehouse operator or ground handling and pilot in command to find the correct procedures in implementing dangerous goods handling of Lithium Battery in the near future.
\end{abstract}

Keywords: Lithium Battery; Implementation; Flight Safety

\section{Introduction}

The important of this paper to maintain flight safety and zero accident against mishandling of Lithium battery as air cargo. Learning from the fact that the carriage of Lithium Batteries as air cargo is increasing exponentially and we must act now to prevent further loss of life. (Captain Michael Moody Jr, Paul Vislosky Chairman IPA Safety Committee \& IPA Director of Airline Safety, 2015). " "from market trends, it is anticipated that safety may still act as a restraint in the search for acceptable compromise with overall performance and cost of lithium-ion based and post lithium-ion rechargeable batteries of the future"(Abada et al., 2016). "Lithium batteries character is high specific energy, high efficiency and long life. These unique properties 
have made lithium batteries the power sources of choice for the consumer electronics market with a production of the order of billions of units per year" (Scrosati \& Garche, 2010). Total outgoing is 155.7 ton and incoming is 174.9 ton, so overall total Is 330,6 ton of electronic (computer, hand phone and camera), while only $50 \%$ according to staff handling has potential involve Lithium battery. The problem is Consequently, incidents involving lithium batteries create the fire on board aircraft. It is not always possible to determine the cause of such incidents, but where to determine the cause; they are invariably due to non-compliance with the requirements. Field incidents that result in fire of battery cells and packs of lithium ion chemistry are still a matter of discussion and cast doubts on the readiness of the technology for applications that require more energy (longer life) or more power (higher current) (Cabrera-Castillo, Niedermeier, \& Jossen, 2016). However, the degree to which the involve of lithium batteries in these incidents (i.e., still could not determine whether they were the cause or aggravated the fire). FAA recorded, around 171 Air/Airport incidents involving batteries carried as cargo or baggage. According to the FAA, there have been more than 40 lithium battery incidents involving smoke, fire, extreme heat or explosion in air transportation since the introduction of lithium batteries in the early $1990 \mathrm{~s}$. The incidents both in the passenger cabin and in cargo compartments when ship batteries as cargo on passenger and cargo-only aircraft. Lithium battery fires may be the result of external short circuit due to contact with other batteries or metal, internal short circuit due to design deficiency, manufacturing defect, damage, or exposure to an external fire or heat source. Counterfeit batteries often lack safety features and poor manufacture, leading to a higher likelihood of being involved in an incident. Additionally, while the investigations are ongoing and made no final determinations, have suspected lithium batteries play a role in several major hull loss accidents.

To certify Lithium ion batteries must pass a series of safety tests for use in a particular application such as portable electronics or automotive. "In International, national and regional standard describe Safety tests, typically developed based upon pre-normative research and experience from industry, 
academia and regulatory bodies" (Ruiz et al., 2017). From the matter above. IPA (Independent Pilot Association) on its recommendation to require all operators for both passenger and cargo, to perform a Risk Assessment of the carriage of Lithium Batteries within Their current operation. 1) must declare, document, mark, and package fully all transport Lithium Batteries as dangerous goods; 2) Create a proximity/quantity limit for the Shipment via air of Lithium Batteries, as well as Segregation standards with the other Dangerous Goods; 3) Require packaged all transport Lithium Batteries so that the hazardous effects associated with thermal runaway must remain within the package; 4) Require a minimum and maximum state of charge for Lithium-ion Batteries and Cells during transport; 5) Require all Operators engage in the transport of Lithium Batteries to only carry such packages within an aircraft compartment, or container, with an active fire suppression system or other proven means of mitigating the risk of a Lithium Battery thermal event). The authority or the operator need to analyze the specific issue against the public policy and the Ministerial decree socialized are the sub regulation of the Indonesian laws as the legal standing in handling the safe transport of Lithium battery. Transportation Minister has standardized The Regulation based on the reference, transportation, environment and Health to find the solution to Lithium battery handling. The scope review is within area of warehouse line 1 and airside or aircraft of Indonesia as well as main gateway. The panel result has concluded 10 points : 1) Determine Lithium batteries in large quantities on the exact size and should notify to the pilot in command; 2) If amend of The section II Provisions when offer to an Operator require lithium batteries must separately from other non-dangerous cargo, at DGP/23 agreed for all other types of dangerous goods, adequate provisions to enable notification to the pilot in command without requiring full regulation of section II batteries may exist; 3) Shippers of Large quantities of Lithium batteries should receive training commensurate with their responsibilities; 4) Packing instruction 965 and 968 should be clarified in respect of training required for operator's staff ; 5). should inspected prior to loading and after unloading for Large quantities of lithium batteries; 6). 
Section II should provide for Electronic Data Processing; 7). Should review hazard communication for Section I batteries; 8). Should report to ICAO the Incidents involving lithium batteries for publishing on a publicly accessible web site; 9). DGP should recommend that ICAO should review the fire suppression abilities of Class E cargo compartment; 10). DGP should recommend to the Operation Panel that they review whether a crew complement of 2 is adequate for cargo aircraft above certain size. (Presented by G A Leach, 2012). 2 major types of lithium batteries power are lithium ion batteries, including lithium ion polymer and lithium metal batteries. 1) Lithium ion batteries are typically rechargeable, and power devices such as laptop computers, mobile phones and portable music players, while 2) nonrechargeable lithium metal batteries, for power devices including cameras, flashlights and Automatic External Defibrillators. A single cell composes for lithium metal battery, while maybe between 6 and 12 cells compose for lithium ion laptop battery. As cargo on passenger aircraft no longer permit the Lithium metal batteries, Prohibition does not apply to lithium metal batteries packed with or contained in equipment (PI 969 / PI 970). UN3090 Lithium metal batteries, now shown as "forbidden" for passenger aircraft. New A201 assigned against UN3090 States concerned may grant an exemption to permit lithium metal batteries on passenger aircraft States issuing exemption must provide a copy to ICAO within 3 months of issue. (CASA and Current IATA DGR, 2017) divided Lithium battery into 6 types of packing instruction and $3 \mathrm{UN}$ no 3480, 3481 and 3091 as follows: 1) PI 965 for UN3480 with Proper shipping name (PSN) Lithium Ion Batteries on their own); 2) PI 966 for UN3481 with PSN Lithium Ion Batteries-packed with equipment; 3) PI 967 for UN3481with PSN Lithium Ion Batteriescontained within equipment; 4) PI 968 for UN3091with PSN Lithium Metal Batteries - on their own; 5) PI 969 for UN3091 with PSN Lithium Metal Batteries -packed with equipment; 6) PI 970 for UN3091 with PSN Lithium Metal Batteries contained in equipment (Lithium Battery Transport information Version 3 July 2015). While there are other UN number 3171 with Special Provision A21, Truck, Locomotives, self-balancing vehicles, 
self-propelled farming/construction equipment PI 952 If could handle Vehicle other than in upright position, require strong outer packaging, must secure vehicle in packaging, and detach also classify separately Batteries from vehicle as batteries on their own or packed with equipment. The safety concerns are not restricted to baggage and cargo. Carry Mail extensively on-board passenger aircraft, both internationally and on relatively short domestic flights. Do not permit Lithium batteries, whether on their own or packed with equipment, in airmail. Nevertheless, numerous web sites advertise lithium batteries for sale with delivery by airmail as an option. Couple this with the fact that a number of such batteries may not comply with the regulatory requirements, it is not surprising that there have been a number of incidents involving lithium batteries in airmail. Re-chargeable lithium ion batteries powered the majority of these devices, which can represent a fire hazard if damage, over-heat, over-charge or store inappropriately. There are currently no reports in the medical literature of lithium ion battery burns related to EC use and no guidance on the appropriate management of lithium ion battery associated injuries (Nicoll, Rose, Khan, Quaba, \& Lowrie, 2016) " There is also a lack of guidance specifically on the management of lithium ion battery burns". Lithium ion batteries are widely used in various types of electronic components, such as laptops, cameras and mobile phones, due to their efficient gravimetric and volumetric energy density, high power density, long service life and pollution-free use. (Scrosati, 2000; Omara 30 et al, 2014). Clearly, for not declared Lithium battery to operator, the above measures are not possible. Therefore, must make efforts to detect such batteries. These include implementing enhanced cargo acceptance processes and training to better detect non-compliant shipments. This could include greater scrutiny of the descriptions of goods on accompanying paperwork. additional training for cargo terminal personnel to increase awareness of the need to better detect damaged packages, remove damaged packages from the transport stream, etc. 


\section{Method}

Preparation upon acceptance, $1^{\text {st }}$ step, Check Approval from DGCA (Directorate general Civil Aviation). For the airline staff, Check state Variation from Indonesia RI01 Carrier must have approval from DGCA $.2^{\text {nd }}$ step, Check Any Embargo/Restriction from Carrier, for the agent, Check operator Variation from International Regulation either ICAO TI or IATA DGR latest edition. Most of the incidents because of noncompliance have invariably, but "undeclared" i.e. Shipper declaration accompany this shipment, but may not protect inadequately against short-circuit. Consequently, operators may wish to consider accepting lithium batteries only from approve shippers and freight forwarders. Such approval could seek to satisfy those requirements such as UN testing, protection against short circuit, the compliance of correct use of packaging and training. Provision for passenger and crew on Table 2.3.A IATA DGR, must extra careful when accept the 7 items below figures, All lithium-ion (Li-ion) batteries require a Battery Management System (BMS). This is due to the fact that all Li-ion batteries will fail if overcharged, completely discharged or operated outside their safe temperature window. Each Li-ion cell type has its own safe operating area, which makes it necessary to program the BMS accordingly. (Vezzini, 2014). Observe packaging of Lithium Battery, IATA DGR Divided into 4 section of lithium battery's packaging : 1) Section IA , for Lithium Battery with RLI/RLM code under PI965/968 either ion/metal battery UN3480/3090 either for passenger aircraft and cargo aircraft only; 2) Section IB, for Lithium Battery with RLI/RLM code under PI965/968 either ion/,Metal battery UN3480/3090 only for passenger aircraft with maximum weight $5.5 \mathrm{~kg} \mathrm{G}$; 3) Section I. for Lithium battery with RLI/RLM code under PI966/967/969/970 (note : for PI 967/970 no need to use UN packaging); 4) Section II, for Lithium battery with ELI/ELM code under PI965/966/967/968/969/970. There are 3 ways to pack: 1) Battery on their own, as loose cargo; 2) Battery packed with equipment (separately inside), 3) Battery packed within equipment or inside equipment. One of the major risks associated with the transport of batteries and battery-powered equipment is 
short-circuit of the battery as a result of the battery terminals coming into contact with other batteries, metal objects, or conductive surfaces. Must separate Packaged batteries or cells in a way to prevent short circuits and damage to terminals. Packaging must be in a strong outer packaging or be contained in equipment. Lithium battery handling label look like and when is it required, for section II (packing instructions ) 965, 966, 967, 968, 969, 970 and for Section IB of packing instruction 965 and 968 use hazard label class 9 and label Cargo Aircraft Only for Packing Instruction 968. The handling label must have red diagonal hatchings with text and symbols in black on a contrasting background. The minimum dimensions are $120 \mathrm{~mm}$ wide x $110 \mathrm{~mm}$ high. Place for "Lithium ion battery" and/or "Lithium metal battery" Where the packages are of dimensions such that they can only bear smaller labels the label dimensions may be $105 \mathrm{~mm}$ wide $\times 74 \mathrm{~mm}$ high. The design specifications remain otherwise the same. $2^{\text {nd }}$ step , how to document Lithium Battery, An accompanying "Transport Document" is required for all Lithium Battery shipments under Section IB, and for the majority of shipments containing Lithium Batteries falling under Section II. Be aware that for shipments to / within / from Asia might require additional documents. Please contact your local customer service representative for more details. Document must accompany each with an indication that the package contains lithium ion/metal cells or batteries; if the package damage must handle the package with care and that a flammability hazard exists; in the event the package damage must follow special procedures, to include inspection and repacking if necessary; ·a telephone number for additional information; and must place the words "lithium ion batteries" or "lithium metal batteries", and "incompliance with Section II of PIxxx" (Packing instructions number) on the air waybill. By airline request, so Shipper or manufacture must accompany the additional document for section II of PI 965 to 970. And also there is a Check list for airline and certificate of compliance, NOTOC for Lithium Batteries. The summary of document support Lithium battery as carrier responsibility. $3^{\text {rd }}$ step, How to handle Lithium Battery, if confirm 
or suspect to be defective As Airline representative will not accept any shipment with lithium batteries ion or metal and/or damaged, regardless of how the condition is and in any quantities. Ground Handling also will not accept any battery recalled by the battery supplier/manufacturer and any waste meant for recycling or disposal purposes (in any condition). A defective battery may not exhibit any damage at all. Any equipment packed with or containing lithium batteries in particular equipment returned for repair purposes as part of reverse logistics/service parts program exhibiting above mentioned condition, must have the batteries removed from the equipment in order to be accepted for carriage with. Results of Lithium Metal Tests, 1) Halon suppressed the cardboard and electrolyte fire; 2) Thermal runaway propagated rapidly between boxes, despite Halon and extremely low oxygen levels; 3) 3450 cells consumed; 4) Smoke penetrated the mix bay and main deck; 5) Rapid reduction in Halon concentration; 6) Terminate Test due to high ceiling temperature; 7) Special Provisions New A201 assigned against UN3090; 8) States concerned may grant an exemption to permit lithium metal batteries on passenger aircraft; 9) States issuing exemption must provide a copy to ICAO within 3 months of issue. Lithium metal batteries - PI 968, Prohibited on passenger aircraft (CAO only) and Section IA - all parts of the Regulations apply; Section II - Prohibited on passenger aircraft (CAO only). Additional limitations apply; Packages in a consolidation must be presented to the operator separately from non-DG goods; for shipper of freight forwarder, the packages not permit to load as BUP; Packages must bear a CAO label, and Additional statement "Cargo Aircraft Only" or CAO must appear on AWB. Upon acceptance there are 2 kinds of restriction Battery lithium physical condition. 1) Large Lithium batteries or Lithium batteries in large quantities, accept this as Excepted quantity and; 2) Forbid Damaged Lithium batteries for Air transport. When cargo staff or ground handling prepare load sheet for freighter, When plan to or place RFL (DG flammable liquid class 3) near with ELI (lithium ion battery class 9), the response of system will reject automatically and need segregation one position of ULD 
and the response on system stated : danger positions or not ok ( see figure 4) .

While the Significant changed to Lithium Batteries on IATA DGR $59^{\text {th }}$ Edition, on section 9.3.2/Table 9.3.A and revised the provisions of 9.3.2 to introduce segregation requirements for lithium batteries (UN 3480 and UN 3090 only), This aligns to the changes in 5.0.1.5, 5.0.2.11, PI 965 and PI 968. Appendix B In Appendix B.2.2.4 new Cargo IMP codes have been added for UN 3090, Section IA and IB of PI 968/RBM and UN 3480, Section IA and IB of PI 965/RBI. These two new IMP codes facilitate the differentiation of fully regulated lithium batteries (UN 3090 and UN 3480) from those packed with equipment or contained in equipment (UN 3091 and UN 3481), which are currently assigned to RLM and RLI respectively. These changes include: removal of the lithium battery handling label (7.2.4.7). As of 1 January 2019 only the lithium battery mark (7.1.5.5) will be permitted on packages of lithium batteries prepared in accordance with Section IB of PI 965 or PI 968, or Section II of PI 965 to PI 970.

\section{Discussion and Results Result}

Ship Lithium ion batteries in or with equipment, and as packages containing only batteries. While some external protection by the equipment afforded on batteries contained in equipment, incident data have shown that fires involving equipment may still occur. The Federation therefore believes that the regulatory exceptions granted to lithium ion batteries, lithium ion batteries in equipment, and lithium ion batteries packed with equipment must be eliminated, providing for full regulation under the ICAO Technical Instructions for the Safe Transportation of Dangerous Goods by Air. Subject to the following conditions the Provisions in the Technical Instructions would provide that each shipment of lithium ion batteries: 1) Design testing of each battery according to the UN Manual of Tests and Criteria; 2) Protect Each cell or battery from short circuit; 3) Packaging in strong outer UN specification packaging; 4) Provide A Dangerous Goods Transport Document; 5) A Class 
9 Dangerous Goods label on The package; 6) Operator require an acceptance check; 7) Provide A Pilot Notification Form (NOTOC) to the pilot in command; 8) Provide Training to persons preparing batteries for shipment.

The Federation believes that The ICAO Technical Instructions for the Safe Transport of Dangerous Goods must fully regulate lithium metal batteries. The fire characteristics of these batteries and the ineffectiveness of Halon in suppressing a lithium metal battery fire mean that a fire involving a single lithium metal battery could be sufficient to cause the loss of an aircraft. Furthermore, the aircraft successfully suppress an independent fire by Halon system would still provide enough heat to ignite a shipment of lithium metal batteries. (IFALPA, The Global Voice of Pilots, DG Briefing leaflet, August 2011). Apply Firefighting Procedures against incident Lithium Batteries in passenger aircraft, Carriage of lithium batteries on passenger aircraft and cargo aircraft, loading of lithium batteries in cargo compartment with the greatest fire suppression capability. Based on a risk assessment load lithium batteries in cargo compartment with most appropriate mitigation capability/Class $\mathrm{C}$ compartment/alternative with fire suppression capability. Use of fire containment covers (FCC) and Fire-resistant containers (FRC), Class E compartments use FCC to provide additional protection for cargo. So "planning fleet is one of the most important activities of an airline"(Juliater Simarmata, Charles, \& Rizaldy, 2014). Especially fleet with better protection if carrying special cargo like dangerous Goods.

\section{Discussion}

From FGD, the finding state eventhough $1^{\text {st }}$ there is no limit quantity for Passenger who carry Lithium ion Battery as cabin baggage for less than 100 watthour per unit, but IATA may set up the limitation next year that limit for Portable Electronic Devices (PED) will be 15 and for Spare batteries will be 20 units per passenger. $2^{\text {nd }}$ For Notification to captain form (NOTOC), there will be a change to remove technical name during fill in the form, the purpose to avoid miswritten and confusion to the cockpit crew during retrieval of the substance name. and from the NOTOC the captain will know the location also 
able to react based on ERG code. So the conclusion $1^{\text {st }}$ The limitation of battery lithium for passenger also affected the limitation battery lithium as air cargo, therefore more safety in preventing unstable dangerous goods substance (such as Lithium batteries-large size) enter the first gate in terminal and warehouse and more screening before loading and transporting into aircraft. From various type of Lithium Battery, we know how to pack, mark, label, document and handling upon loading and inside aircraft,also know how to act during emergency. $2^{\text {nd }}$ From NOTOC the Pilot can prepareProper system or alert system to prevent incompatibility on cargo compartment, support with proper equipment install on the aircraft, can handle fire during incident. The recommendation, $1^{\text {st }}$ to limit and refer to the airline when there was a doubt about the total quantity carry by passenger and also remind agent to provide test certificates and technical specification for the lithium battery, Then Some general commodity still have risk of containing Lithium battery inside. To strength the acceptance side, need aviation security to prevent the undeclare, miss-declare the commodity by preventing it. Further if any irregularities during acceptance, need all party concerned to raise Incident report to DGCA (Directorate General Civil Aviation), the purpose to apply the regulation properly and make correction for the matter. $2^{\text {nd }}$ The party involve on this dangerous goods handling can implement to create better system and Standard Operating Procedure to prevent the hazard and incident during receive lithium battery as air cargo either via passenger/shipper. "Three main parties associated with the shipment of cargo, namely the shipper/the receiver (consignee); the carrier; and the ground handling/warehouse operator"(Ricardianto \& Rifni, 2016). The other important party is Avition Acurity which is part of "airport operations units are responsible from passengers getting off the vehicle to the terminal to report themselves, entering the waiting room, boarding the plane and last until the plane departs" (Resky \& Simarmata, 2014) 


\section{References}

Abada, S., Marlair, G., Lecocq, A., Petit, M., Sauvant-Moynot, V., \& Huet, F. (2016). Safety focused modeling of lithium-ion batteries: A review. Journal of Power Sources. https://doi.org/10.1016/j.jpowsour.2015.11.100

Azhar, F., \& Rizaldy, W. (2015). Strategies in Enhancing the Qualityservices of Traffic Special. Jurnal Manajemen Bisnis Transportasi Dan Logistik, $82-91$.

Cabrera-Castillo, E., Niedermeier, F., \& Jossen, A. (2016). Calculation of the state of safety (SOS) for lithium ion batteries. Journal of Power Sources, 324, 509-520. https://doi.org/10.1016/j.jpowsour.2016.05.068

Juliater Simarmata, Charles, \& Rizaldy, W. (2014). The Impact of Fuel Increase and Currency Exchange Depreciation on Indonesia Aviation Industry Sustainability. Jurnal Manajemen Transportasi \& Logistik (JMTransLog) $\quad$-, $\quad 1(3), \quad$ 199-208. https://doi.org///dx.doi.org/10.25292/j.mtl.v1i3.18

Kania, D. D. (2016). Analisis Faktor Budaya Keselamatan dan Kesehatan Kerja ( K3 ) Pada Penanganan Kargo Di Bandara Soekarno Hatta International Airport. Jurnal Manajemen Transportasi \& Logistik, 3(1), $1-13$.

Nicoll, K. J., Rose, A. M., Khan, M. A. A., Quaba, O., \& Lowrie, A. G. (2016). Thigh burns from exploding e-cigarette lithium ion batteries: First case series. Burns, 42(4), e42-e46. https://doi.org/10.1016/j.burns.2016.03.027

Resky, M., \& Simarmata, J. (2014). FUNGSI dan KELEMAHAN UNIT OPERASI PELAYANAN DI BANDARA. Jurnal Manajemen Transportasi \& Logistik (JMTRanslog), 1(1), 1-8.

Ricardianto, R. P., \& Rifni, M. (2016). Air Cargo Capacity on Cargo Terminal Development Plan at Soekarno-Hatta International Airport. Jurnal Manajemen Transportasi \& Logistik (JMTRanslog), 1(2).

Ruiz, V., Pfrang, A., Kriston, A., Omar, N., Van den Bossche, P., \& BoonBrett, L. (2017). A review of international abuse testing standards and regulations for lithium ion batteries in electric and hybrid electric vehicles. Renewable and Sustainable Energy Reviews. https://doi.org/10.1016/j.rser.2017.05.195

Scrosati, B., \& Garche, J. (2010). Lithium batteries: Status, prospects and future. Journal of Power Sources. https://doi.org/10.1016/j.jpowsour.2009.11.048

Vezzini, A. (2014). Lithium-Ion Battery Management. In Lithium-Ion Batteries: Advances and Applications (pp. 345-360). https://doi.org/10.1016/B978-0-444-59513-3.00015-7 